\title{
Entrepreneurship Education for Students in Higher Education
}

\author{
Moh. Solehatul Mustofa ${ }^{1, *}$ Noviani Achmad Putri ${ }^{2}$ Tutik Wijayanti ${ }^{3}$ \\ ${ }^{1,2,3}$ Faculty of Social Sciences, Universitas Negeri Semarang \\ *Corresponding author.Email: mustofa@mail.unnes.ac.id
}

\begin{abstract}
The challenges of modern life in today's global era are so complex. Society is more open and the level of competition is getting sharper between one individual and another. This condition has an impact on college graduates in the era of the Industrial Revolution 4.0. Therefore, every graduate in this era is required to have qualified competencies to compete globally. College graduates are required not only to be able to work in government agencies, companies, and other agencies, but also to have an entrepreneurial spirit to create new jobs. This study aims to explain the role of Entrepreneurship Education Higher Education in developing student entrepreneurship; as well as analysing the factors that support Entrepreneurship Education in developing student entrepreneurship. The research was conducted using a qualitative approach. The research location chosen was Semarang State University. Primary data sources came from UNNES students and secondary data sources were obtained through documents, a collection of articles, and documentation. Data collection techniques using observation methods, in-depth interviews, and documentation study. The validity of the data was tested using data triangulation techniques, methods, and theories. Data analysis techniques include data collection, data reduction, data presentation, and concluding (verification). The results showed that Entrepreneurship Education has been developed by universities with very varied methods and processes. However, the success of higher education in producing and producing graduates who can compete in the business world is not only sufficient through Entrepreneurship Education courses. Entrepreneurship education can be effective if it is supported by various supporting components which include training courses for entrepreneurship, internships in large companies, extensive social networks, and support from each family. These elements can be integrated into the Entrepreneurship Education course so that they can become an extraordinary support system to produce graduates who are competitive in this era of disruption.
\end{abstract}

Keywords: College Student, Entrepreneurship Education, Industrial Revolution 4.0.

\section{INTRODUCTION}

The challenges of modern life in today's globalized era are so complex, society will be more open and the level of competition is getting sharper between one individual and another. This condition directly affected college graduates in the era of the Industrial Revolution 4.0. Therefore, every graduate in the current era is required to have qualified competencies to compete globally. College graduates are required not only to be able to work in government agencies, companies, and other agencies, but also to have an entrepreneurial spirit to create new jobs by taking advantage of opportunities that have emerged from the 4.0 Industrial Revolution.

To foster an entrepreneurial spirit in students, it is necessary to make an effort through education. One of these efforts is by providing entrepreneurship education for students in tertiary institutions. This is very important considering that the entrepreneurial spirit cannot just emerge without the support of various efforts to grow it. For students who have backgrounds from entrepreneurial families, getting to know and studying the world of entrepreneurship is certainly no stranger. However, for students from nonentrepreneurial family backgrounds, it certainly takes more effort to be able to understand and practice it.

Seeing the importance of abilities in the field of entrepreneurship, Higher Education is now including entrepreneurship courses in the curriculum in higher education, with the hope of fostering an entrepreneurial spirit in students. This is certainly in line with Government Regulation Number 17 of 2010 which 
states that the goals of higher education include forming critical, creative, innovative, independent, confident, and entrepreneurial people. Entrepreneurship courses in the current curriculum have the benefit of providing knowledge and education to students about entrepreneurship. According to Suherman in Yudhi and Yunita [1] explains that the function of entrepreneurship courses is a learning vehicle to instill an entrepreneurial spirit as the basis of other lessons; foster entrepreneurial attitudes and behavior; provide technical entrepreneurship; provide experience running a business; and foster adaptability in facing various changes in society. Then the entrepreneurship course can function to guide and shape an entrepreneurial spirit and foster entrepreneurial attitudes and behavior so that student interest appears to be able to be entrepreneurial.

Several things highlighted regarding entrepreneurship courses in tertiary institutions are how effective this course is in fostering an entrepreneurial spirit in students. To see further the effectiveness of this course, it is necessary to explore more deeply related to what kind of implementation of entrepreneurship courses have been taking place in tertiary institutions as well as the driving and inhibiting factors of implementing entrepreneurship courses through indepth research.

\section{RESEARCH METHOD}

This research method using a qualitative approach. The research location was conducted at the Semarang State University (UNNES). The primary data sources were 16 students from UNNES representatives from eight faculties in Unnes and 8 lecturers in entrepreneurship courses. In addition, for supporting informants, 2 staff from the Unnes Business Development Agency and 2 staff from the Business Incubator Group. Sources of secondary data in this study are documents, a collection of articles, and documentation. Data collection techniques using observation and in-depth interviews and documentation. Data validity using data triangulation techniques, methods, and theories. Data analysis techniques include data collection, data reduction, data presentation, and concluding (verification).

\section{RESULTS AND DISCUSSION}

\subsection{The Role of Entrepreneurship Education in Higher Education in Developing Student Entrepreneurship}

Globalization as a new life system is an inevitable phenomenon. This situation has several consequences in the social, economic, technological, and cultural fields. This phenomenon also results in changes that are very strategic for the development and national dynamics of a country, because in many cases they also result in a situation of loss of geographic, political, and economic boundaries of the country; including in this case the emergence of an increasingly tighter level of competition between countries to mutually defend national interests. This competition does not only occur between countries but also competition between people. To anticipate the above changes, higher education institutions need to change the educational paradigm from the pattern of old industrial education is a new entrepreneurial education, to encourage the creation of a "knowledge-based economy". Remember the motto "knowledge is power". To improve the nation's competitiveness, Higher Education as an institution that develops "knowledge" needs to improve the quality of student resources so that they become competent graduates. Competent graduates are not only able to master knowledge and technology in their fields, but also the ability to apply their competencies and have skills soft adequate.

The role of higher education must be able to provide provisions for its graduates not only hard skills but also soft skills sufficient for students. Hard skills, among others, consists of knowledge by the field of study being pursued (knowledge of the field) and knowledge of technology (knowledge of technology). Meanwhile, soft skills include the ability to communicate both orally, in writing, and pictures (oral and written communication), the ability to work independently or in a team (ability to work independently and in a team setting), logical skills, and analytical skills. The reality in the field shows that to reach the peak of success, not only hard skills are needed, but also soft skills. In fact, in many ways, a person's excellence in soft skills is an important factor that determines the success of his life. The student's self-potential which consists of creativity, feeling, and intention which will be actualized in his "work", both achievements and creations, must be continuously honed and developed to form an entrepreneurial spirit and insight into his independence as a provision for future success after becoming a tertiary education alumnus. That's where the importance of an entrepreneurial spirit and independence.

Entrepreneurship is the spirit, attitude, behavior, and/or that leads to efforts to seek, create, and implement new ways of working, technology, and products to increase efficiency to provide better service and/or gain greater benefits. In other words, entrepreneurship is also knowledge about values, souls, attitudes, and actions based on the spirit of added value, so that it is reflected in thinking, acting, and acting that prioritizes innovation, creativity, and independence. Entrepreneurship education is one form of application for the care of the world of universities for the development of Indonesian human resources. In entrepreneurship education, values and forms of work are shown to achieve success. Their mindset, attitude, 
and behavior are also shaped so that one day they become a true entrepreneur. Students are directed to choose entrepreneurship as a career choice. Entrepreneurship education at PT has enormous benefits for students in developing their academic potential and personalities. These benefits include (1) opportunities to hone an entrepreneurial spirit; (2) improve student soft skills by being directly involved in the world of work; (3) increasing students' courage to start a business; and (4) obtaining capital support and assistance in an integrated manner.

The strategy to build students' entrepreneurial spirit with the Entrepreneurship Education course is one of the valuable investments made by the government in the Human Resources by preparing students to start new businesses through the integration of experiences, skills, and knowledge received by students. Thus, after graduating from a tertiary institution, they have the choice of a career to become a proud young entrepreneur.

The important role of PT in creating young entrepreneurs in a country has been emphasized by Zimmerer [2]. According to him, one of the driving factors for entrepreneurial growth in a country lies in the role of universities through the implementation of courses related to the field of entrepreneurship. PT is responsible for providing entrepreneurial skills to its graduates by forming attitudes, behaviors and changing old mindsets that can only look for work, not create new jobs. The development of entrepreneurial spirit for education students is intended to provide provisions for students so that students/alumni higher have a mindset, attitude pattern, and action patterns that prioritize innovation, creativity, and independence. Entrepreneurship is an ability that can be learned, so entrepreneurship education needs to be provided on an ongoing basis or it must be instilled continuously to produce graduates with entrepreneurial insight/entrepreneurship.

Entrepreneurship education in tertiary institutions is also related to building entrepreneurial character, an entrepreneurial mindset, and entrepreneurial behavior that is always creative and innovative creates added value or good values (values), takes advantage of opportunities, and is brave to take risks. Facing the challenges of a highly competitive future, entrepreneurial behavior is necessary for all occupations or professions. Therefore, entrepreneurship education can be implemented in higher education and applied to all students regardless of the field of study being studied because entrepreneurship education is not business education. In addition, the role that can be given through the existence of entrepreneurship courses in tertiary institutions has a positive impact on the development of student interest in cultivating the world of entrepreneurship. An increase in student interest in developing the world of entrepreneurship reduces the number of unemployed and indirectly increases state income through taxes. If efforts to increase the number of young entrepreneurs continue to increase, Indonesia can be free from the crisis that is currently wrapping the economy. Entrepreneurship education is important to apply in universities in any major to produce graduates who are ready to enter the world of work, either as part of a corporation or as a corporation owner. Higher education graduates are expected to have an entrepreneurial mentality that is obtained from entrepreneurship education, namely as a job opening, not as a job seeker.

\subsection{Supporting Factors of Entrepreneurship Education in Student Entrepreneurship Development}

The results of this paper indicate that entrepreneurship education has been developed by almost all existing universities and of course with very varied methods and processes to create entrepreneurship. However, the fact is that the success of higher education in producing and producing graduates who can compete in the business world is not only enough through the Entrepreneurship Education course that has been given when students are studying. Entrepreneurship education can be effective when it is supported by various existing components. The elements of the supporting components that can produce students to become reliable business actors are necessary.

\section{a. Entrepreneurship Courses}

Education Entrepreneurship courses at Semarang State University are regulated in a curriculum that has been integrated with the University curriculum which is then lowered at the Faculty level to become Joint Courses. This Entrepreneurship Curriculum which is implemented in lectures is compiled comprehensively at both the University and Faculty levels. In formulating entrepreneurial learning and training systems/methods, the Faculty of Social Sciences has seriously designed entrepreneurship courses/materials for students, starting from making syllabus, teaching event units (SAP), presentation slides, theory modules. The formulation was certainly done by a team that is truly expert and experienced in various fields of science. In addition, it is not only lecturers who are involved in the formulation of the curriculum but also involve several related parties such as practitioners/business actors and entrepreneurial motivators as curriculum compilers. The goal is that this curriculum can provide the needs that exist in the field. So that the courses/material given in the lecture are contextual. Collaboration in curriculum development is very important considering that collaboration between academics, practitioners, and motivators will produce 
entrepreneurial concepts and ideas that are appropriate and suitable for students from various scientific disciplines. Developing an entrepreneurship curriculum does not necessarily make entrepreneurship a separate subject, but the content of entrepreneurship is possible to include some / all courses. However, there is one thing that is still lacking in the implementation of Entrepreneurship Education at the Faculty level, namely the absence of practicum/practice modules, making entrepreneurship manuals, etc. This of course in the future needs to be followed up more seriously.

\section{b. Establishment of the Entrepreneurship Center}

Many entrepreneurial activities have been carried out in the UNNES environment such as the Student Creativity Program (PKM), particularly PKMK (PKM Entrepreneurship) and Cooperative Education (Co-op). Furthermore, the Entrepreneurial Student Program (PMW) is implemented which is a continuation of previous programs (PKM, Co-op, KWU, MKU, KKU) to bridge students into the world of business real through the facilitation of business start-ups. But these activities are not yet in the container, so they are not running sustainably. To provide a forum for entrepreneurial activities at UNNES, a design for the establishment of the National Entrepreneurship and Productivity Development Center (P2KPN) on September 23, 2010. From the results of this design, the UNNES Student Entrepreneurship Center (UNSEC) was created on October 10, 2010. In line with the need, UNSEC was given the additional mandate to become a career center. Therefore, UNSEC must become the UNNES Student Entrepreneurship and Career Center (UNSECC) in 2011. This activity center is a form of a forum to support the implementation of entrepreneurship courses at the Faculty of Social Sciences in particular and UNNES in general.

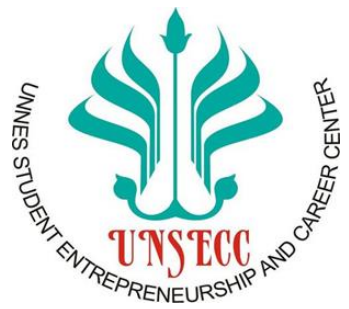

Figure 3.1 Student Entrepreneurship and Career Centre (UNSECC)

c. Career Guidance and Entrepreneurship Course Training Activities

Career guidance is a voluntary co-curricular activity with Diploma and Undergraduate student participants. Conducted in semester II, III, or IV within a few days, depending on the type of guidance required. The types of guidance programmed include 1) Training courses for several skills (designing, sewing, cooking, workshops, etc.) and providing entrepreneurial career support; 2) Psychological tests for selection and recruitment for students who will take part in Entrepreneurship development activities at UNNES; 3) Career planning in entrepreneurship. The output of entrepreneurial career guidance activities is so that students can develop themselves and their potential in the field of entrepreneurship.

\section{d. Entrepreneurship Internship}

The internship is a voluntary Co-Curricular activity with Diploma and Undergraduate student participants. Conducted in semester IV, V, or VI, within one to three months. Duties of Entrepreneurship Internship Participants: assisting tasks/jobs at the Business Entity concerned and help solve problems in the Business Entity concerned. Activities carried out in the Entrepreneurship Apprenticeship Program are as follows: Providing internships; Implementation of internships; Monitoring and evaluation; Results seminar and reporting; Follow-up (Preparation Business Plan and Guidance and assistance). The output of the Entrepreneurship Internship activity itself is so that students can identify business opportunities and students have the motivation to start a business.

\section{e. Business Incubator Group}

The Business Incubator Group (GIB) Institute for Research and Community Service (LPPM) Semarang State University (UNNES) is one of the groups in UNNES which aims to produce students to become reliable entrepreneurs in their fields. This cluster is a form of Union's commitment to developing and encouraging the academic community to create entrepreneurship activities. The purpose of establishing the GIB UNNES is as a forum for the downstream and commercialization of research, community service, and UNNES fostered partners, both from within and outside the country. The UNNES business incubator program is intended to provide services to the academic community, both from students who are starting a company (start-up) and the results of commercial research inventions by UNNES lecturers in the field of food focus. With this program, it is hoped that strong young entrepreneurs will be born. Through this program, various activities to strengthen business management and innovation capacity are carried out to create a climate for the growth and development of new entrepreneurs in UNNES. For the GIB to continue running well, cooperation and extensive networks are needed. Therefore, GIB is collaborating with banks and several other distributors. This GIB is a form of commitment from the leadership of UNNES in developing the incubator program, which is located in the Prof. Dr. Retno Sriningsih Satmoko UNNES building. GIB facilities and infrastructure on the first and third floors are used to support business activities. 


\section{f. Extensive Social Networking / Cooperation}

It is important to do this by the Faculty of Social Sciences and universities in the framework of three objectives, namely (1) improving the quality of human resources for lecturers and students; (2) opening business internship opportunities for lecturers and students; and (3) opening opportunities for business cooperation, especially for students or alumni. With This cooperation, the program is expected that students can especially analyse and observe real business forms so that they have a picture of when they become entrepreneurs. So, from not only the theory given by the lecturer but there needs to be a network of cooperation with other parties to develop and be knowledgeable in entrepreneurial practice.

\section{g. The existence of a Business Unit for Students}

One of the sincerity of universities in realizing students to become entrepreneurs is the need to form several business units that are managed by students, regardless of the type of business, of course, it must be by the agreement between the student and the campus institution. The business units that are formed can be used as a valuable experience for students before plunging into opening a business independently. So far, this business unit at the Faculty of Social Sciences has not yet formed a cluster but is still at the level of student organizations that are included in the Student Association. So it is necessary to immediately form an Entrepreneurship group both at the student and lecturer level.

\section{h. Student Entrepreneurship Expo}

Student Entrepreneurship Expo is activities that support the strengthening of the implementation of Entrepreneurship courses in the Faculty of Social Sciences. This activity aims to encourage, train, and develop talents, interests, potentials, and skills soft possessed by students, one of which is through entrepreneurship, not just material in Entrepreneurship courses but organized through student entrepreneurship competitions and expos. The Dean of FIS through this activity also appealed to UNNES FIS students to be brave in entrepreneurship. Students with a spirit of change and idealism can certainly give birth to creative ideas as well as new interesting ideas according to the times. Several approximately 63 entrepreneurial student groups participated in this activity with great enthusiasm. Students start to pursue and develop various types of businesses according to their talents, interests, and potential. This activity has succeeded in producing 10 best students in entrepreneurship who have received awards and development money from the Faculty of Social Sciences. One group of students who received the best predicate was Food product creation from tofu dregs, this creation won the best award out of the top 10 best entrepreneurial students. Student Entrepreneurship
Competitions and Expo can be a place to promote student businesses. It is hoped that current students dare to start entrepreneurship and change the mindset of job seekers to become job creators. This is one of the activities carried out at the Faculty of Social Sciences as a form of supporting the implementation of Entrepreneurship courses.

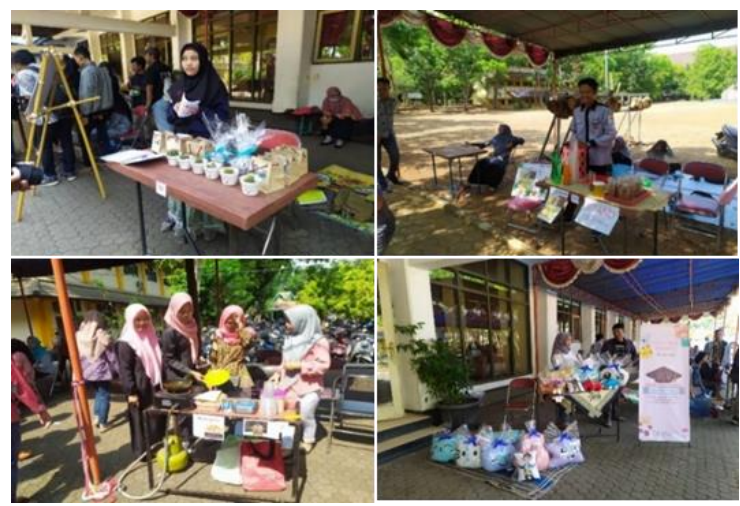

Figure 3.2 Faculty of Social Sciences UNNES Student Entrepreneurship Expo Activities

\section{i. Eduvlog Digital Entrepreneurship Development Activities}

Facing the industrial era 4.0 requires skills in the use of technology and the internet. Therefore, one of the efforts of the Faculty of Social Sciences in encouraging students to be technology-based entrepreneurs is by forming an eduvlog community. Vlogs or video blogs or video logs are currently very trendy on the Internet. In the past, maybe what we knew was only the term blog or blogging, but now it turns out that there are many other terms, one of which is Vlog. The development of Vlog until now has experienced quite significant developments. Since the emergence of YouTube, the development of this Vlogger is indeed quite popular in many countries. However, for Indonesia, the development of Vlogs has not been that long. Not many Vloggers were active before 2012. It was only after 2012 that Indonesians made many popular channels appear on YouTube. Then after 2014, Indonesian vloggers began to emerge who were able to provide a variety of viral content that rocked the world. This phenomenon is the background of the Faculty of Social Sciences to encourage students to become entrepreneurs in the field of eduvlog. This activity has been running several times so that it has succeeded in producing several eduvlog products. This activity is also in line with the Faculty of Social Sciences which is engaged in education. In addition to training students to be able to do entrepreneurship on a technology basis, it is also a means of providing a lot of information and knowledge from the material presented by speakers from various fields. 




Figure 3.3 Edu-vlog Activities in Faculty of Social Sciences UNNES

\section{j. Entrepreneurship Students Program}

A strengthening program to encourage entrepreneurial activities and accelerate the growth of new entrepreneurs has announced that the government, the Directorate General of Higher Education, has developed a variety of entrepreneurship programs. In 2009, the Entrepreneurial Student Program (PMW) was introduced to bridge students into the real business world through existing business facilities. On the other hand, systematic student clicker extra activities can also build motivation and entrepreneurial mental attitudes. This has been implemented by the Faculty of Social Sciences through field three, encouraging students to be able to compete through the PKM program carried out by the directorate general of higher education.

\section{k. Support from Family}

Research conducted by Pereira et al. [3] also stated that the support of the family environment has a positive effect on one's entrepreneurial intentions. The higher the support, the more it will encourage children to become entrepreneurs and vice versa. Shen, Osorio, and Settles [4] also reveal their research which shows that family support has a positive effect on a person's desire and eligibility to start a business. Shen et al. [4] revealed that the family is conceptualized and assessed as a context for individual entrepreneurial intentions, the support that is felt from the family can play an important role in individual behavior and life choices. Based on the results of research related to family support in entrepreneurial intentions, the type of family support in the form of guidance and advice is the support that most influences to increase entrepreneurial intentions. This is in line with the results of research conducted by Fradani [5] showing that support from family has a positive influence on a child's entrepreneurial intentions. Likewise, research conducted by Herdijono, Puspa, and Maulany [6] shows that family has a positive influence on entrepreneurial intentions in a child. The family is expected to be able to provide guidance on what the child is doing and provide useful advice for the child so that they can further increase their entrepreneurial intentions. According to Alma [7], being an entrepreneur is the result of parental or family support because this support can encourage a child. The job of an entrepreneurial parent can also trigger a child to become an entrepreneur by following in the footsteps of parents to determine the career or job to be taken in the future.

Based on the results of research related to entrepreneurial personality in entrepreneurial intentions, having knowledge about entrepreneurship and having an orientation in the future will have the most influence on increasing entrepreneurial intentions. Students need to strive to instill an entrepreneurial spirit and deepen knowledge about entrepreneurship, by joining the entrepreneurial community, actively participating in learning or training on entrepreneurship, and participating in entrepreneurship seminars. Attitude for high enthusiasm to move forward must also be instilled to create an entrepreneur. When combined and integrated with the existence of Entrepreneurship Education courses in tertiary institutions, these important elements can become a support extraordinary system to produce graduates who are ready to be competitive in this era of disruption. Therefore, Entrepreneurship Education or entrepreneurship will be increasingly encouraged in higher education so that college graduates can be independent and are no longer focused on being job seekers.

\subsection{Type of entrepreneurship carried out by students of the Faculty of Social Sciences}

Based on the results of research, various types of businesses that have been carried out by several students of the Faculty of Social Sciences are as follows: Rice Bowl, Online Shop, HP Accessories and Pekalongan Quota, Oriflame Cosmetics, Graduation Buckets, JualBeliTas / Clothing, Graduation Bucket, Pulse Selling, donuts, robe, hijab accessories, hijab, sweater reseller, Solo Batik Shirt Online Shop, Afa'a Snack, Convection, Clothing, Meatball Tofu, Meatball Tofu, KainTenun, Bukalapak Pulsa Agent, notebook design, totebag, Potato Hotdog, Crispy Banana, Manjaddawajadahijaab, HNI-HPAI (herbal products), Clothing Shop, Online Shop Printing Services Polaroid Photos, Selling HP Accessories, Selling Hijabs, Baby Equipment and Supplies, Selling Veils, Health and Beauty Products, Selling Clothes, Bags, Accessories, Multi Payment, Selling Fruit Salad, Selling Shoes and Bags, Selling and Buying Apple Cider Vinegar and Organic Masks, Selling Food, Selling Buff Masks, Selling and Buying Featured Products PT Duta Persada, Make Up, Sell Clothes, Edelweiss Angkringan Classic, Sell Token Credit, Quota, Sell Bags, Sell Books, Sell Batik, Batik Cloth, Batik Dress Lamongan, and food, Clothing, Batik, Online Shop, Official member of Nu Amoorea products (MLM business ), Online Shop 
(clothes, flash disks, masks, lamps), Online Shop (socks), Online Shop Coverings.

\section{CONCLUSION}

Entrepreneurship education is one form of application of concern from the world of Higher Education for the development of Indonesian human resources. The role of Entrepreneurship Education in Higher Education can provide benefits for students including providing opportunities for students to hone their entrepreneurial spirit; improve soft skills student by being directly involved in the world of work; increase the courage of students to start a business; as well as obtaining capital support and assistance in an integrated manner. In addition, entrepreneurship education in tertiary institutions is also related to building student character. This character is related to the entrepreneurial mindset and entrepreneurial behavior that is always creative and innovative creates added value or good values, takes advantage of opportunities, and is brave to take risks. The factors that support Entrepreneurship Education in developing student entrepreneurship at Semarang State University include: Entrepreneurship courses; Establishment of an Entrepreneurship Centre; Career Guidance and Entrepreneurship training course activities; Entrepreneurial internship; Business Incubator Group (GIB); Extensive social network/cooperation with the business world; There is a business unit for students; Entrepreneurship demo activities (pamphlet demo expo activities); Eduvlog digital entrepreneurship development activities; Entrepreneurial Student Program (PMW); as well as full support from the family. Entrepreneurship education is important to apply in universities in any major to produce graduates who are ready to enter the world of work, either as part of a corporation or as a corporation owner. Higher education graduates are expected to have an entrepreneurial mentality that is obtained from entrepreneurship education, namely as a job opening, not as a job seeker. Hopefully, the suggestions that can be given in the results of this article are to encourage students through various entrepreneurial activity programs at Semarang State University on an ongoing basis, it is hoped that students will be more motivated to start entrepreneurship.

\section{REFERENCES}

[1] Yudhi, R. F., \& Rahmat, Y. (2014). Pengaruh Pembelajaran Mata Kuliah Kewirausahaan Terhadap Minat Mahasiswa Program Studi Akuntansi Untuk Berwirausaha., vol. 15 no. 1.

[2] Zimmerer. W Thomas, Norman M. Scarborough. 1996. Entrepreneurship and New Jersey: Prentice Hall International Inc. hal 51.
[3] Periera, A., Mashabi, N. A., \& Muhariati, M. 2017. Pengaruh dukungan orangtua terhadap minat anak dalam berwirausaha (pada siswa SMK Strada Koja, Jakarta Utara). Jurnal Kesejahteraan Keluarga dan Pendidikan, 4(2), 70-76.

[4] Shen, T., Osorio, A.E., and Settles, A. 2017. Does family support matter? The influence of support factors on entrepreneurial attitudes and intentions of college students. Academy of Entrepreneurship Journal, 23(1), 24-43.

[5] Fradani, A.C. 2016. Pengaruh dukungan keluarga, kecerdasan adversitas dan efikasi diri pada intensi berwirausaha siswa SMK Negeri 2 Bojonegoro. Jurnal Edutama, 3(1), 47-62.

[6] Herdijono, I., Puspa, Y.H., dan Maulany, G. 2017. The factors affecting entrepreneurship intention. International Journal of Entrepreneurial Knowledge, 5(2), 5-15.

[7] Alma, B. 2013. Kewirausahaan untuk mahasiswa dan umum. Bandung: Alfabeta. 